\title{
APLIKASI ALAT PENUKAR KALOR PADA TEKNOLOGI THERMAL ROOFING
}

\author{
Subroto, Nurmuntaha, Aris Hartanto \\ Jurusan Teknik Mesin Fakultas Teknik Universitas Muhammadiyah Surakarta \\ Jl. A.Yani Tromol PosI Pabelan Surakarta \\ email:sub224@ums.ac.id
}

\begin{abstract}
ABSTRAK
Studi ini ditujukan untuk mengetahui pengaruh material insulasi Glaswool, Styrofoam dan Alumunium foil terhadap besarnya kalor yang dikonduksikan atap fiber, utamanya pada atap rumah tangga. Penggunaan panas di bawah atap rumah masih sangat jarang dilakukan, dimana panas ini bisa dimanfaatkan untuk memanasi air hangat untuk mandi, atau sejenisnya.

Metoda yang dilakukan adalah dengan mengukur temperatur pada titik yang terdistribusi di ruang atap yang ada, kemudian menghitung aspek perpindahan panas yang terdistribusi meliputi volume di bawah atap tersebut.

Dari hasil penelitian diperoleh hasil kalor tertinggi yang dikonduksikan oleh atap fiber terdapat pada atap yang di dalamnya terdapat material insulasi Glaswool yaitu sebesar 1145,338 Watt, sedangkan pada alumunium foil sebesar 1045,338 Watt dan pada Styrofoam sebesar 1124,513 Watt. Oleh karena itu, kalor tertinggi pada ruang atap terdapat pada ruang atap dengan material insulasi Glaswool yaitu sebesar 1167,184 Watt, sedangkan Alumunium foil sebesar 1065,164 Watt dan styrofoam sebesar 1114,721 Watt.
\end{abstract}

Kata kunci: penukar kalor, kondusi, glasswool, stereofoam, aluminium foil.

\begin{abstract}
This study is aimed to determine the effect of Glaswool, Styrofoam and Alumunium foil insulation materials on the amount of heat that is conducted by fiber roof, primarily on the roof of the household. The use of heat under the roof of the house is still very rarely done, where this heat can be used to heat water for bathing.

The first step to perform this experiment is measure the temperature at points which are distributed in the existing roof space. After that, we calculate the distributed heat transfer on all volume under the roof.

The result shows that the highest heat conduction is 1145.338 Watt, produced by Glaswool insulation, while the aluminum foil is 1045,338 Watt and the Styrofoam is 1124,513 Watt. Therefore, the highest heat in roof space is in the roof space with Glaswool insulation material which is 1167,184 Watt, while Alumunium foil is 1065,164 Watt and Styrofoam is 1114,721 Watt.
\end{abstract}

Keywords: heat exchanger, conduction, glasswool, stereofoam, aluminum foil. 


\section{PENDAHULUAN}

Dalam kehidupan di muka bumi ini, ketergantungan terhadap bahan bakar fosil sangat memprihatinkan misalnya hampir semua kegiatan sehari-hari dalam bidang industri, rumah tangga dan transportasi menggunakan $75 \%$ bahan bakar fosil. Sedangkan saat ini ketersediaan bahan bakar fosil semakin menipis yang disebabkan untuk mendapatkan minyak bumi dibutuhkan waktu yang sangat lama. Pembakaran bahan bakar fosil sendiri mengakibatkan polusi gas dan efek rumah kaca (terutama gas $\mathrm{CO}_{2}$ ). Ketidakstabilan harga bahan bakar fosil yang cenderung naik terus menerus akibat dari permintaan kebutuhan bahan bakar fosil lebih besar dari pada produksi bahan bakar fosil itu sendiri menjadi permasalahan yang akan terus dihadapi selama kita masih menggunakan bahan bakar fosil.

Untuk daerah Indonesia yang sesuai untuk mensubtitusi sumber energi dari bahan bakar fosil adalah energi surya karena Indonesia terletak di daerah khatulistiwa yang sepanjang tahun selalu mendapat sinar matahari. Selain itu energi surya memiliki keunggulan yaitu energi yang tidak polutif, bersifat kontinyu dan tersedia dialam bebas dalam jumlah yang sangat besar. Semua itu merupakan alasan utama dalam pengembangan dan pemanfaatan energi surya. Maka yang diperlukan sekarang adalah bagaimana dapat memanfaatkan sumber energi matahari sebagai energi alternatif untuk mensubtitusi sumber energi dari bahan bakar fosil.

\section{TUJUAN PENELITIAN}

a. Mengetahui pengaruh material insulasi Glaswool, Styrofoam dan Alumunium Foil terhadap besarnya kalor yang dikonduksikan atap Fiber.

b. Mengetahui besarnya kalor yang dikonduksikan material insulasi Glaswool dan Styrofoam serta seberapa besarkah kalor yang diserap oleh material insulasi Alumunium Foil sebagai kalor yang hilang.

c. Mengetahui pengaruh material insulasi Glaswool, Styrofoam dan Alumunium Foil terhadap besarnya kalor yang terdapat pada ruang atap.

\section{TINJAUAN PUSTAKA}

Archibald (2003), mengadakan penelitian mengenai BIST (Building Integrated Solar Thermal) dengan menggunakan teknik pengumpulan panas. John Archibald membuat solar thermal roofing sebagai suatu aplikasi dari proses penyerapan dan pengumpulan energi matahari melalui atap rumah. Sistim thermal roofing ini bertujuan untuk mengurangi biaya produksi dalam mendapatkan energi panas. Dalam penelitiannya John Archibald menggunakan material atap yang berbeda- beda yaitu logam, kaca, dan plastik dan dengan formasi pemasangan yang berbeda. Dengan variasi tersebut sistem thermal roofing dapat menyuplai energi panas pada ruangan-ruangan dengan kapasitas sendiri-sendiri seperti yang diinginkan.

Astaputra (2007) melakukan penelitian tentang teknologi thermal roofing pada bulan April. Hasil yang didapatkan yaitu semakin kecil sudut kemiringan atap semakin besar temperatur pada ruang atap, dengan demikian kalor yang dapat diserap pun menjadi besar. Atap dengan sudut kemiringan $35^{\circ}$ mampu menyerap panas paling besar jika dibandingkan dengan sudut $40^{\circ}$ dan $45^{\circ}$ karena semakin kecil sudut kemiringan atap semakin besar luas permukaan atap yang terkena radiasi matahari. Selain itu dapat diketahui pula posisi atap terhadap matahari akan mempengaruhi besarnya temperatur pada ruang atap. Posisi atap yang dapat menyerap kalor paling besar jika atap diposisikan menghadap timur karena jumlah radiasi matahari yang dapat diserap pada posisi tersebut lebih besar. Pada penelitian yang dilakukan oleh Astaputra (2007) tentang teknologi thermal roofing belum menunjukkan hasil yang maksimum. Hal tersebut dikarenakan karena pada ruang atap yang diteliti 
tidak tertutup secara maksimal, hal ini memungkinkan adanya aliran udara yang masuk ke ruangan atap. Tidak adanya material insulasi di dalam ruangan atap memungkinkan terjadinya pelepasan kalor. Selain itu hasil pengukuran belum maksimal hal ini dikarenakan pengukuran menggunakan thermometer manual yang tingkat keakurasiannya rendah serta mudah terpengaruh udara luar.

\section{HASIL DAN PEMBAHASAN}

Pengaruh Material Insulasi Glaswool, Alumunium Foil dan Styrofoam Pada Thermal Roofing Terhadap Kalor yang Dikonduksikan Atap Fiber

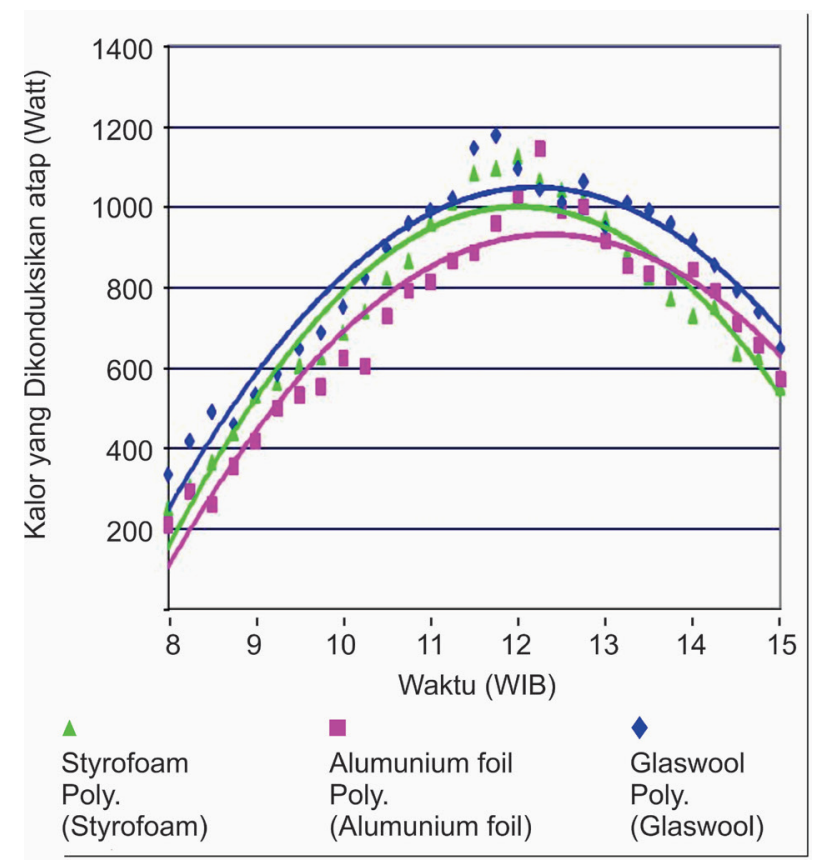

Gambar 1. Pengaruh Material Insulasi Pada Thermal Roofing Terhadap Kalor yang Dikonduksikan Atap Fiber

Mulai jam 08.00 WIB sudah ada kalor yang dikonduksikan atap fiber, seiring dengan penambahan waktu terjadi peningkatan kalor yang diterima thermal roofing hingga mencapai kalor maksimal yang dikonduksikan atap fiber pada kisaran waktu 11.30-12.15 WIB dikarenakan adanya peningkatan intensitas sinar matahari. Selanjutnya seiring dengan penambahan waktu terjadi penurunan kalor yang dikonduksikan atap karena adanya penurunan intensitas sinar matahari. Atap fiber yang di dalamnya terdapat material insulasi Glaswool dapat mengkonduksikan kalor lebih besar dibandingkan dengan atap fiber yang di dalamnya terdapat material insulasi Styrofoam maupun alumunium foil. Kalor maksimal yang dikonduksikan atap fiber dengan material insulasi Glaswool yaitu sebesar 1176,338 Watt, Kalor maksimal yang dikonduksikan atap fiber dengan material insulasi Styrofoam yaitu sebesar 1124,513 Watt, dan Kalor maksimal yang dikonduksikan atap fiber dengan material insulasi alumunium foil yaitu sebesar 1045,338 Watt.

\section{Pengaruh Material Insulasi Glaswool, Alumunium Foil dan Styrofoam Pada Thermal Roofing Terhadap Kalor yang Dikonduksikan Material Insulasi}

Kalor yang dikonduksikan insulasi semakin meningkat seiring dengan penambahan waktu hingga mencapai kalor maksimal pada kisaran waktu 11.45-12.15 WIB yang dikarenakan 
adanya peningkatan nilai gradien temperatur material insulasi. Selanjutnya seiring dengan penambahan waktu terjadi penurunan kalor yang dikonduksikan insulasi karena adanya penurunan nilai gradien temperatur insulasi. Penurunan kalor yang dikonduksikan Glaswool lebih sedikit dan stabil penurunannya dibandingkan dengan Styrofoam maupun Alumunium foil, hal ini dikarenakan Glaswool memiliki kemampuan thermal storage yang lebih tinggi dibandingkan dengan material insulasi Styrofoam maupun Alumunium foil.

Pada material insulasi Glaswool kemampuan konduktifitasnya paling rendah dalam menghantarkan kalor dibandingkan dengan material insulasi Styrofoam maupun Alumunium foil. Ini berarti Glaswool paling bagus digunakan sebagai insulasi karena semakin kecil mengkonduksikan kalor maka semakin kecil pula kalor yang akan terbuang keluar. Kalor maksimal yang dikonduksikan material insulasi Glaswool yaitu sebesar 13,076 Watt sedangkan kalor maksimal yang dikonduksikan material insulasi Styrofoam adalah sebesar 19,773 Watt dan kalor maksimal yang dikonduksikan material insulasi Alumunium foil adalah sebesar 80,173 Watt.

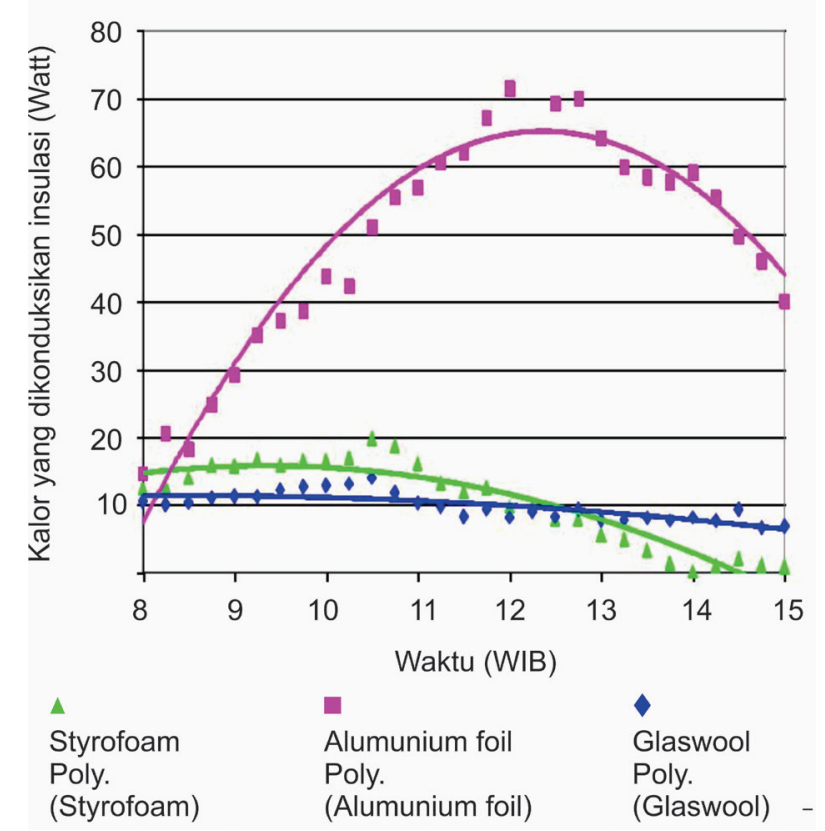

Gambar 8. Pengaruh Material Insulasi Pada Thermal Roofing Terhadap Kalor yang Dikonduksikan Insulasi

\section{Pengaruh Material Insulasi Glaswool,Alumunium foil dan Styrofoam Pada Thermal Roofing terhadap Kalor pada Ruang Atap}

Ketika memulai penelitian jam 08.00 WIB sudah ada kalor yang terdapat pada ruang atap hasil dari radiasi matahari, seiring dengan penambahan waktu terjadi peningkatan kalor pada ruang atap yang dikarenakan adanya peningkatan intensitas sinar matahari hingga mencapai kalor maksimal. Pada ruang atap dengan material insulasi Glaswool memiliki kalor ruangan tertinggi pada jam 11.45 WIB sebesar 1167,184 Watt, sedangkan material insulasi Styrofoam memiliki kalor ruangan tertinggi pada jam 12.00 WIB sebesar 1114,721 Watt dan material insulasi Alumunium foil memiliki kalor ruangan tertinggi pada jam 12.15 WIB sebesar 1065,164 Watt . Selanjutnya seiring dengan penambahan waktu terjadi trend penurunan kalor pada ruang atap karena adanya penurunan intensitas sinar matahari.

Pada ruang atap dengan material insulasi Glaswool memiliki kalor ruangan yang lebih besar dibandingkan dengan ruang atap dengan material insulasi Styrofoam maupun Alumunium foil. Hal ini dikarenakan kemampuan Glaswool dalam mengkonduksikan kalor 
lebih rendah sehingga tidak banyak kalor yang terbuang. Sedangkan pada alumunium foil kalor pada ruang atap lebih rendah karena banyak kalor yang terbuang atau yang terserap didalamnya.

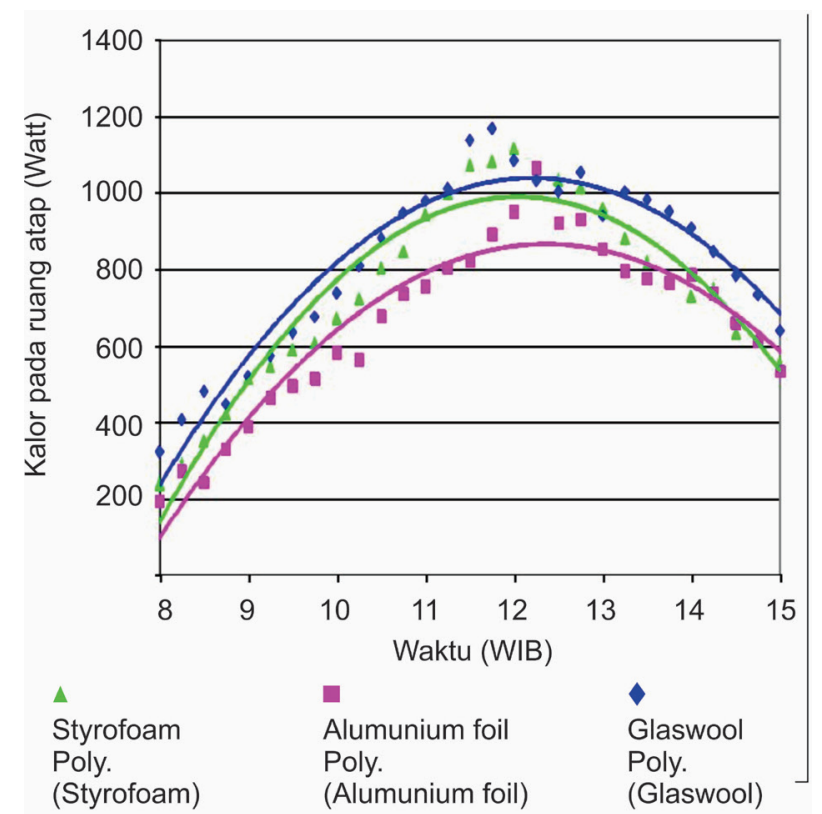

Gambar 9. Pengaruh Material Insulasi Glaswool,Alumunium foil dan Styrofoam Terhadap Kalor Pada Ruang Atap

\section{KESIMPULAN}

Dari hasil analisa dan pembahasan dapat diambil suatu kesimpulan sebagai berikut:

1. Kalor tertinggi yang dikonduksikan oleh Atap fiber terdapat pada atap yang di dalamnya terdapat material insulasi Glaswool yaitu sebesar 1145,338 Watt, sedangkan pada alumunium foil sebesar 1045,338 Watt dan pada Styrofoam sebesar 1124,513 Watt.

2. Pada material insulasi semakin kecil kalor yang dikonduksikan semakin kecil kalor yang akan terbuang keluar. Sehingga Kalor maksimal yang dikonduksikan material insulasi Glaswool yaitu sebesar 13,076 Watt adalah yang paling kecil dibandingkan dengan Alumunium foil sebesar 80,173 Watt dan styrofoam sebesar 19,773 Watt .

3. Kalor tertinggi pada ruang atap terdapat pada ruang atap dengan material insulasi Glaswool yaitu sebesar 1167,184 Watt, sedangkan Alumunium foil sebesar 1065,164 Watt dan styrofoam sebesar 1114,721 Watt .

\section{SARAN}

1. Perlu adanya pengoptimalisasian insulasi dari suatu model thermal roofing, sehingga pelepasan kalor dapat diminimalisir.

2. Perlu adanya pengoptimalisasian dari suatu model thermal roofing, sehingga kalor yang terdapat pada ruang atap dapat dimanfaatkan secara optimal.

\section{DAFTAR PUSTAKA}

[1] Agustinus, D., 2007, Kebutuhan Energi Dunia, http://don85.wordpress.com, diakses tanggal 31 Mei 2008 jam:20.00 
[2] Archibald, J., 2003, Building Integrated Solar Thermal Roofing System History, Currents Status, And Future Promise, American Solar Roofing Company, America.

[3] Astapura, P.M., 2007, Analisa Thermal Roofing Menggunakan Material Asbes Dengan Variasi Sudut Dan Orientasi Arah Matahari, Tugas Akhir, Fakultas Teknik Jurusan Mesin Universitas Muhammadiyah Surakarta.

[4] Colon, C.J., 2001, Roof Integrated Solar Absorbers: The Measured Performance of Invisible Solar Collector, National Renewable Energy Laboratory, Colorado

[5] Culp, A.W., 1996, Prinsip-Prinsip Konversi Energi, terjemahan Darwin Sitompul, Erlangga, Jakarta.

[6] Ditjen Listrik dan Pemanfaatan Energi, 2001; ZREU, 2000.

[7] Holman, J.P., 1993, Perpindahan Kalor, Erlangga, Jakarta.

[8] Kadir, A., 1995, Energi, Universitas Indonesia, Jakarta.

[9] Kreith, F., 1994, Prinsip-Prinsip Perpindahan Panas, Erlangga, Jakarta.

[10] Yulianto, B., 2007, Krisis Energi di Indonesia, http/www. Berita iptek.com, diakses tanggal 31 Mei 2008 jam:20.30 